\title{
Author Correction: Time for (Research on) Change in Mathematics Departments
}

\author{
Daniel L. Reinholz ${ }^{1} \cdot$ Chris Rasmussen $^{1} \cdot$ Elena Nardi ${ }^{2}$ \\ Published online: 18 June 2020 \\ (C) Springer Nature Switzerland AG 2020
}

\section{Author Correction: International Journal of Research in Undergraduate Mathematics Education.}

https://doi.org/10.1007/s40753-020-00116-7

In the original version of this article, the acknowledgement is missing. It is provided below:

Acknowledgements Support for this work was funded by the National Science Foundation under Grants \# 1624639 and \# 1830897. Any opinions, findings, and conclusions or recommendations expressed in this material are those of the authors and do not necessarily reflect the views of the National Science Foundation.

Publisher's Note Springer Nature remains neutral with regard to jurisdictional claims in published maps and institutional affiliations.

The online version of the original article can be found at https://doi.org/10.1007/s40753-020-00116-7

Daniel L. Reinholz

daniel.reinholz@sdsu.edu

1 Department of Mathematics \& Statistics, San Diego State University, San Diego CA 92182-7720 USA

2 University of East Anglia, Norwich Research Park Norwich Norfolk NR4 7TJ UK 